Terbit online pada laman web jurnal : http://e-journal.sastra-unes.com/index.php/JILP

\begin{tabular}{|c|c|c|}
\hline \multirow[b]{2}{*}{$\begin{array}{c}\text { Fakultas Sastra } \\
\text { Universitas Ekasakti } \\
\end{array}$} & \multicolumn{2}{|c|}{$\begin{array}{c}\text { (Jurnal IImiah Langue and Parole) } \\
\text { Volume } 4 \text { Nomor } 2\end{array}$} \\
\hline & $\begin{array}{c}\text { ISSN : 2581-0804 } \\
\text { (Media Cetak) }\end{array}$ & $\begin{array}{c}\text { E-ISSN : 2581-1819 } \\
\text { (Media Online) }\end{array}$ \\
\hline Received: 19-07-2021 & Revised: $25-07-2021$ & Available online:10-08-2021 \\
\hline
\end{tabular}

\title{
TYPE AND STRATEGY OF CODE SWITCHING USED BY ENGLISH TEACHERS IN THE PROCESS OF TEACHING AND LEARNING ENGLISH
}

\author{
Julian Chandra ${ }^{1}$, Siska Oktawidya Wati ${ }^{2)}$ \\ *STKIP YDB, English Education Program, Juchandra71@ gmail.com \\ *STKIP YDB, English Education Program, Siskaoktawidyawati@gmail.com
}

\begin{abstract}
The purpose of this research were: (1) to describe type of using code switching and (2) to describe the strategy behind the use code switching made by English teachers in English language eaching and learning at SMAN 1 Padang Sago. This research used descriptive qualitative design. The population were all English teachers in the school who taught English subject for $10^{\text {th }}, 11^{\text {th }}$ and $12^{\text {th }}$ graders in the 2019 academic year. The purposive sampling technique was employed in the research in which the total sampling were all 5 English teachers. Instrumens to collect the data were observation chceklist and interview. In the observation checklist, all teachers' utterancess were categorized according to the types and strategies of the code switching belong to. To determine the frequency of the type and strategy of the code switching emerging in observation checklist, the numberof the type and strategy that emerged were count manulay. Then, the percentage formula $P=\frac{F}{N} * 100 \%$ was used. Then, the interview was used to validate the result gained from the observation checklist. Finally, among 110 utterances, it was found there was 4\%, of tag switching used by the tecaher, inter-sentential switching was $36 \%$, and intra-sentential switching was 60\%,. On the other hand, among 10 strategies of code switching proposed by Hoffman (1991), it was found that the teacher preferred to use only 4 strategies only of which are for scosiisted of expressing solidarity $48 \%$, interjection $7 \%$, repetition 28\%, and clarification 19\%).
\end{abstract}

Keywords: Code Switching; .Strategy; Type Of Code Switching; Teaching And Learning Process

(C) 2021Jurnal JILP

\section{INTRODUCTION}

In daily interaction, bilingual or multilingual community usually tends to choose different "codes" in different situation for certain purposes. For example, a particular code may be used to make a particular topic easier to be understood for both parties in conversational encounter. A code is a system that is used by people to communicate with each other. When people want to talk each other, they have to choose a particular code to express their feeling.

According to Stockwell (2002), a code is a symbol of nationalism that is used by people to speak or communicate in a particular language, or dialect, or register, or accent, or style on different occasions and for different purposes. Similarly, Ronald Wardaugh (2006) also maintains that a code can be defined as a system used for communication between two or more parties used on any occasions. When two or more people communicate each other in speech, we can call the system of communication that they employ a code. Therefore, people are usually required to select a particular code whenever they choose to speak, and they may also decide

Jurnal JILP (Jurnal Ilmiah Langue and Parole) Vol. 4 No. 2 (2021) ISSN : 2581-0804

This work is licensed under a Creative Commons Attribution-NonCommercial 4.0 International License. 
to switch from one code to another, sometimes in very short utterances and it means to create a code

Holmes (2001) defines the codes switching as the speaker's changing from one language code to another one. It explains code switching is not only occurs when someone switches the language but also switches the code (dialect, intonation etc.). While, According to Gumperz (2014), code switching means the juxtaposition whithin the same speech exchange of passages of speech belonging to two different grammatical systems or subsystems

Surely, in classroom context especially in the context of teaching and learning English as a foreign language, the phenomena of English teachers switch from English to Bahasa Indonesia as students' first language or vise versa in delivering and explaining particular topic or subject of English lesson is something unavoidable and frequently to happen. Regardless, there is the contraversy whether English teachers are inappropriate to switch one language into another language as for providing EFL learners the authentic classroom environment to acquire successfully and naturally the second language they are learning. However, recent studies suggest that code switching actually become part of the process of acquiring the second language and that it may be an important a required competence in the way speakers ability to alternate between the two languages for succesful communication (McKay, 2005).

For this regard, some researcher like Chrichly (1999), Burden (2001), Greggio \& Gill (2007) had claimed that code switching can be used by the teacher as a tool in assisting for the better of English teaching and learning process in the classroom. While others, for example Skiba (1997), Tien \& Liu (2006) view that code switching gives EFL learners the opportunity to develope a new language they are learning because code switching provides the effective transfer of information from the sender to the recivers. Particularly, for the low language proficiency students, code switching will help them to get better comprehension in the process of learning a new language because they are provided with a both equivalent understanding

Furthermore, Harmer (2007) says communication with students is essential to effective teaching. To communicate successfully, teacher must know how to structure their own language output for maximum clarity. They must also have strategies for understanding what students are said, because understand students talk is key to analyze students knowledge to make them understand and what teaching strategies would be useful. Not only the students but also the teachers usually uses their native language and English language alternately as it is called as "code switching"

Accroding to Namba (2012), code switching is the alternative used by bilinguals of two or more languages in the same conversation, has attracted linguists' attention and been studied from a variety perspectives. Holmes ( 2013) states that code switching occurs when the speaker shifts from one language to another or when the speaker switches from one code to another. It explains code switching is not only occurs when someone switches the language but also switches the code (dialect, intonation etc).

One of the main aims of EFL (English Foreign Language) teachers is to get students speaking as much as possible, as it is known that to promote communicative competence, learners must get practice in communicative exchanges in the classroom. (Hancock, 1997)

Jendra (2010), mentions that there are two types of code switching situational and metaphorical. A situational code switching appears when there is a change in the situation that causes the bilingual switches from one code to the other. A metaphorical code switching happens when there is a change in the perception, or the purpose, or the topic of the conversation

While Poplack (1980), from another viewpoint, proposed a well known framework that identifies three different types of code switching which are tag-switching, intersentential and intra-sentential

Tag-switching involves inserting a tag or short phrase in one language into an utterance that is otherwise entirely in another language. Tag-switching requires only little integration of the two languages. Tags include interjections, fillers and idiomatic expressions. Inter-sentential involves switching at sentential boundaries where one clause or sentence is in one language and the next clause or sentence is in other. In addition, Intra-sentential involves the greatest syntactic risk as words or phrases from another 
language are inserted into the first language within on sentence or utterance. As two languages are mixed within a sentence, there are also two different grammars in play which means that the speaker has to know both grammars in order to produce a grammatically correct utterance.

Furthermore, Hoffman (1991), mentions list of strategies/or reasons why for bilingual or multilingual person to switch their languages. Thore are (1) Talking about a particular topic, (2) Quoting somebody else, (3) Being emphatic about something expressing solidarity, (4) Interjection/ inserting sentence fillers or sentence connectors, (5) repetition used for clarification, (6) intention to clarifying the speech content for interlucutor, (7) expression of group idenity, (8) to soften or strenghten request or command, (9) for real lexical need, 10) to exclude other people when a comment is intended for only limited audience.

In addition, Namba (2012) states that :as the alternative use by bilinguals of two or more

\section{RESEARCH METHODS}

The design of research was descriptive qualitative. It is the design which focus on describing a phenomenon without giving treatment to the students. This design also allows the researcher to describes a phenomenon by presenting the facts in rich detail without attempt to interpret them Population of this research were all of English teachers in SMAN 1 Padang Sago. The research used purposive sampling technique.where total population of 6 English teacher at the school were taken as sample of the reserach.

The first instrument employed in order to gain the data was observation aiming to gain comprehensive picture or general description of code switching made by teacher in classroom. During the class observation, observation checklist was provided to write down any teachers' utterances indicating the use of code languages in the same conversation, however code switching has attracted linguists' attention and been studied from a variety perspective. A numbr of studies have been conducted dealing with this code switching phenomena. For example,

In addition, according to Riehl (2005), code switching is a widespeard phenomenon in bilingual speech, and it is therefore not suprising that a great proportion of research on bilingualism. It means that code switching happens because people use more than one language in communication. Therefore, for this regard, viewing the need for the comprehensive study external factors that contribute to the success of second language teaching and learning in the classrrom, therefore, this research was directed to answer the following questions: 1) what type of code switching used by English teachers, and 2) what strategies the teacher intend to use the type of code switching in the teaching and learning English in the classroom.

switching during the teaching and learning process in the classroom.

The second instrument used in this research was an interview. It was employed in order to gain the information that could not be revealed in classroom observation, such as mind, thought, and feeling of the participants through classroom observation and document analysiS.In addition, to avoid misunderstanding, the interview was used to confirm some unclear results of classroom observation in an attempt to complete the data. Cresswell (2007) assumes that interview is good since the question can be limited by the researcher due to the need of the interview. To determine the frequency each of type and strategies occur, so the data from observation checklist were analyzed with percentage formula as follow:

Formula: $P=\frac{F}{N} * 100 \%$ 


\section{RESULTS AND DISCUSSION}

\section{by The Teachers}

1. Types of Code Switching Used

Based on the data analysis, among the 110 utterances it was found that the types of code switching made by English teachers comprised were tag switching $4 \%$ from 4 utterances, intersentential switching $36 \%$ from 40 utterances, and intra-sentential switching $60 \%$ from 66 utterances. The result of types of code switching made by English teachers during learning process in the classroom is illustrated in following table 1 and figure 1 :

\section{Table 1}

Result of Type of Code Switching

\begin{tabular}{ccc}
\hline $\begin{array}{c}\text { Types } \\
\text { of } \begin{array}{c}\text { Fode } \\
\text { switching }\end{array}\end{array}$ & $\begin{array}{c}\text { Fuency } \\
\text { querce }\end{array}$ & ntage \\
\hline Tag & 4 & $4 \%$ \\
$\begin{array}{c}\text { Switching } \\
\text { Inter- }\end{array}$ & 40 & $36 \%$ \\
$\begin{array}{c}\text { Sentential } \\
\text { Switching } \\
\text { Intra- }\end{array}$ & 66 & $60 \%$ \\
$\begin{array}{c}\text { Sentential } \\
\text { Switching }\end{array}$ & & \\
\end{tabular}

Figure 2

Percentage of Types of Code Switching

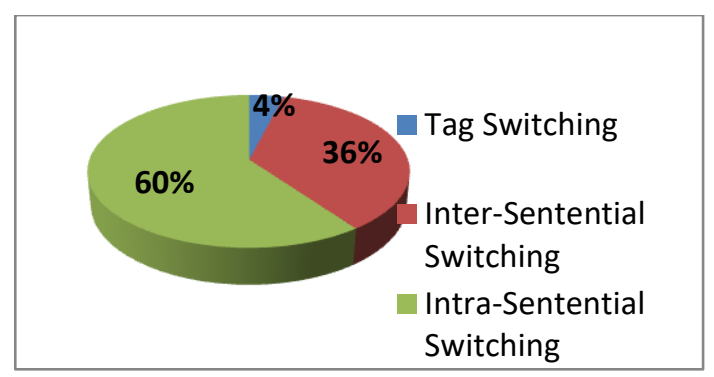

\section{Strategies of Teacher's Using the Code Switching}

Based on the data analysis, among 110 utterances made by English teacher during the teaching and learning process it was found that strategies or reasons of teachers' using of code switching consist of expressing solidarity $48 \%$ from 53 utterances, interjection $7 \%$ from 8 utterances, repetition $26 \%$ from 28 utterances, and clarification 19\% from 21 utterances.The result of strategies of the code switching is illustrated in the following table 2 and figure 2 :

Table 2

Strategies of Code Switching

\begin{tabular}{ccc}
\hline $\begin{array}{c}\text { Type } \\
\text { s }\end{array}$ & $\begin{array}{c}\text { Fre } \\
\text { quency }\end{array}$ & $\begin{array}{c}\text { Perc } \\
\text { entage }\end{array}$ \\
\hline $\begin{array}{c}\text { Expre } \\
\text { ss Solidarity } \\
\text { Interj }\end{array}$ & 53 & $48 \%$ \\
ection Repet & 8 & $7 \%$ \\
ition Rep Rlarif & 28 & $26 \%$ \\
ication & 21 & $19 \%$ \\
Ren
\end{tabular}

Figure 2

Percentage of Strategies Used in Code Switching

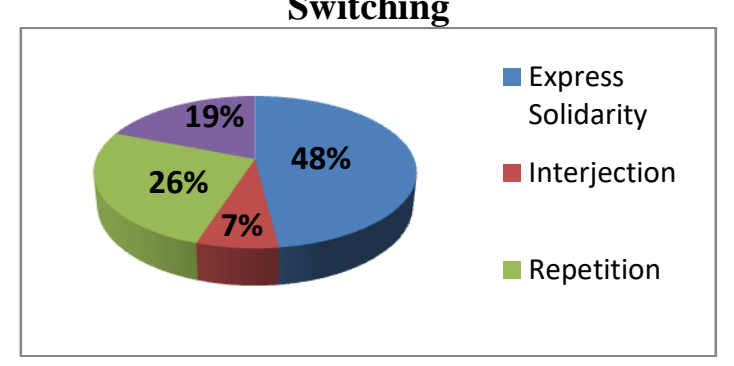

Some list of utterences made by the English teachers at SMN 1 padng Sago can be seen as follow as:

Table 3. The Use of Tag Switching

\begin{tabular}{lc}
\hline $\begin{array}{l}\text { Type of code } \\
\text { switching }\end{array}$ & \multicolumn{1}{c}{ Utterances } \\
\hline & I. Okay, actually \\
& today ya in our plan to \\
perform in performance in \\
Tag switching & front of the class. It is \\
& right? Yes. \\
& II. How about \\
& homework? Finish? Are \\
& finish homework-nya? \\
& III. Denied, \\
& denied verb one-nya deny. \\
& IV. Fitria, no \\
& reading ya you reading.
\end{tabular}


.According Poplack (1980), the insertion of tag to an utterance has virtually no ramifications for the rest of the sentence. This is because tags have no syntactic constrains, they can move freely, and they can be inserted almost anywhere in a discourse without violating any grammatical rules. As it can be seen from utterances I, II, III and IV in table 3, the insertion of prefix -nya and exclamation ' $\boldsymbol{y} \boldsymbol{a}$ " of bahasa indonesia merely functions as "filler" inserted into English that are being used in the process of teaching and learning in the classroom indicating the use of tag switching .

\section{switching.}

Table 4. The Use of Intra sentential

\begin{tabular}{l} 
Type of \\
code \\
switching \\
\hline
\end{tabular}

Intra-

sentential switching
Utterances

I. Oke, kamu nggak

bisa seratus because untuk pertama kali untuk struktur itu belum lengkap seharusnya ada negative-nya, ada introgativenya. Setelah itu yang kedua kamu penutupan parting no English.

II.Mungkin itu artinya
bahwa bagaimana
mengungkapkan expression love. iii.Tentang expression love, how to the way express to expressing love, you can use right in the white board.

$$
\text { IV.To other, jangan }
$$

ketawakan orang tapi kalau kita tidak mampu.

V.What do you mean? Dia mengatakan rasia atau rahasia? Kalau rasia yang dibawo $k a$ rumah anduang rayo tu nak? Rahasia, secret.

VI.Apa? She cook? Oh took, membawa. Apa yang ditaken-nya? Buku, kamus, dompet? Ulangi. Ada yang tertinggal

$$
\text { VII.Are you sure }
$$

melewatkan angka 100 ?

VII.Kan tadi ini don't think love never minded ya, kita mencintai itu hanya dengan pikiran yang apa.

VII.Ini banyak lagi yang there are some many expression, there are some many way how to express your love, banyak sekali.

IX She taught sedangkan kita memakai verb two, teach kita ganti dengan taught, apa yang di-taught-nya? Objeknya dulu English, she taught English, boleh ada keterangan tempatnya, adverb of place keterangan tempat, in the class, in the room, in the library dan dimana-mana pokoknya tempat.

The characteristic of intra sentential switching is swicthing occurs within the unit of syntactis between two languages like words, phrases, clauses or even a complete sentence. Table 4 shows the examples of utterences Engish teachers switched Indonesian into English or English into Indoensian language alternatively indicating the use of intra sentential switching

Table 5. The Use of Inter Sentential

\section{Switching}

\begin{tabular}{lc|}
$\begin{array}{l}\text { Type of code } \\
\text { switching }\end{array}$ & \multicolumn{1}{c}{ Utterances } \\
\hline & $\begin{array}{l}\text { I. She taught } \\
\text { English in this class. Dia } \\
\text { mengajar bahasa Inggris di } \\
\text { kelas ini. }\end{array}$ \\
\hline
\end{tabular}

II. Ada pertanyaan sampai disini? Any question? Ndak ada yang bertanya?

II. Oke. Do you have homework today? Ada? Do you have homework?

IV. Homework ya. Who didn't do the homework? Rise your hand, who didn't do homework? Yang tidak membuat PR?

Jurnal JILP (Jurnal Ilmiah Langue and Parole) Vol. 4 No. 2 (2021) ISSN : 2581-0804 


\begin{tabular}{ll}
\hline & One? Only one? \\
Inter sentential & \multicolumn{1}{c}{ IIV. Oke, buka. Open } \\
switching & your book! Open your book \\
about your homework! \\
VI. Okay, how do you \\
think about this video? Ya, I \\
see someone cry, and then \\
may be someone dreaming. I \\
don't know what do you \\
think about now. Kemana \\
melayang pikiran kamu \\
sekarang setelah melihat \\
video ini? $\quad$ VII. Sorry ya, yang \\
kemaren ada tambahannya \\
dari X IPA 4 karena dia \\
belum tau atau kita udah \\
masuk, baru hari ini \\
pertemuan pertama. Berarti \\
nanti ibuk catatkan \\
indikatornya untuk materi \\
sama KD nya, kamu kasih \\
jarak dulu nanti pinjam \\
sama teman yang ada disini.
\end{tabular}

Okay, Do you understand?
IX. Ihsan, lengkap?

How many words are there in paragraph one?

Table 5 shows some of English teachers' utterances dealing with the use type of inter sentential switching within English or Bahasa Indonesia. For example, in the utterences $1 \mathrm{~V}$, it clearly seen how teacher switched into Bahasa Indonesia in form of sentence in the purpose to maintain the classroom discourse: .." homework 'ya"? Who didn't do the homework? Rise your hand who didn't do the homework! Yang tidak membuat PR? One? Only one? The Utterance $\mathrm{V}$, shows how teacher gave command sentence using imperative and immadiately switch into Bahasa Indonesian language using the same imperative...Oke, Buka! Open your book! Open your book about your homework!

\section{CONCLUSION}

Based on the findings, it was concluded that the English teachers at SMA N 1 Padang Sago tend to use intra sentential switching as the type of code switching from English into Indonesian language or Indoensia into English. The type used comprised $60 \%$ of total 110 utterances Language in the teaching and learning process.. Whereas tag switching was $4 \%$ and inter-sentential switching $36 \%$ of the total utterances. Strategies of using code switching in the teaching and learning English in the classroom were for expressing solidarity $48 \%$, for interjection $7 \%$, for repetition $26 \%$ and for clarification $19 \%$ of total 110 utterances. The findings are quite different from some other studies. For example, Afifah (2020) found the most frequency of type used by teachers was tag switching, while other two types of code swicth are realtively the same. Also Amalia (2021) who studied junior high school teachers' using code switching during online teaching and learning, found that inter sentential switching was used the most. 


\section{Bibliography}

[1] Amalia, lia. 2021. Code Switching Used by teachers at Islam Tirtayasa Junior High School. Jurnal of English language teaching and Literature. 4(1): 23-32

[2].Afifah, Nur. 2020. An Analysis of Code switching Used by an Engish Teacher in Learning Process. Research in English and Education (READ), 5 (1), 19-25.

[3].Burden, P. (2001). When do native English speakers and japanese College Students disagree about the use of Japanese in the English Conversation Classroom? The language Teacher, April 2001. http://www.jalt-publication org/tlt/article 2001/04/burden. Acessed on 2020-07-28.

[4].Creswell, J. W. (2012). Educational research: Planning, conducting, and evaluating quantitative and qualitative research 4th edition. Boston: University of Nebraskaâ€"Lincoln

[5].Critchley, M. P. 1999. Bilingual support in English classes in Japan: a survey of students opinions in L1 use by foreign teachers.

[Online] Available:http://www.jaltpublications.org/t lt/articles/1999/09/critchley. Accessed on 2015-08- 30.

[6].Greggio, S. \& Gil, G. 2007. Teacher's and Learner's Use of Code-Switching in the English as a Foreign Language Classroom: a qualitative study. Linguagem and Ensino. $\quad 10 \quad 371$ 393.[Online]Available:http://rle.ucpel.tche .br/php

/edicoes/v10n2/02Greegio\%20e\%20 Gil. Accessed on 2020-08-29.

[7].Grumperz, J. 1982. Discourse Strategies. London: Cambridge University Press

[8].Hancock, M. (1997). Behind Classroom Code Switching: Layering and Language Choice in L2 Learner Interaction. TESOL Quarterly. https://doi.org/10.2307/3588045
[9].Hoffman, C. 1991. An Introduction to Billingualism. london: Longman

[10].Harmer, J. (2007). The Practice of English Language Teaching Fourth Edition. In Cambridge: Pearson Longman.

[11].Holmes, J. (2013). An Introduction to Sociolinguistics. In An Introduction to Sociolinguistics. https://doi.org/10.4324/9781315833057

[12].Jendra, M.I.L. 2010. Sociolinguistics: The Study of Societies Language.Yogyakarta: Graha Ilmu

[13].McKay, S. L. (2005). Sociolinguistics and second language learning. In Handbook of Research in Second Language Teaching and Learning. https://doi.org/10.4324/9781410612700-26

[14].Namba, K. (2012). Non-insertional codeswitching in English-Japanese bilingual children: Alternation and congruent lexicalisation. International Journal of Bilingual Education and Bilingualism. https://doi.org/10.1080/13670050.2012.66 5829

[15].Poplack, S. 1980. Sometimes I'll start a sentence in English y termino en espanol: toward a typology of code switching. Linguistics 18: 581-618

[16].Riehl, C. M. (2005). Code-switching in Bilinguals: Impacts of Mental Processes and Language Awareness. The 4th International Symposium on Bilingualism.

[17].Skiba, R. 1997. Code-Switching as a Countenance of Language Interference. (Online), http://www.melbourne.starway.net.a u. Accessed on 2015-08-14

[18]Wardhaugh, R. 2006. An introductioto Linguistics. USA: Blackwell Publishing. 